\title{
Mapping of North-Western Anatolia by the Lénard Expedition
}

\author{
János Jeney \\ Institute for Hungarian Studies - jeney.janos@mki.gov.hu
}

\begin{abstract}
In 1918 the Hungarian Government sent a group of experts and scientists, to investigate the coastal region of Northern Anatolia with a view to promoting future Hungarian-Turkish economic relations. The brief of the expedition was to carry out technical, geological, economic and ethnographic surveys. They left Haydarpasa on 21 September 1918, and arrived a month later in Ereğli, where they decided to return home. While some of the group returned by ship to Istanbul, the rest travelled overland and studied an area south of the coastal district. The material collected by the expedition was hidden in a safe place in Istanbul. On 1 December the party was interred as prisoners of war, only being able to take a ship to Trieste on 7 January 1919 from where they travelled by train to Hungary. One manuscript of an ethnographic map with a scale of 1:200000 was brought back by István Györffy. This is by far the most detailed ethnographic map made of this part of Anatolia where many Balkanian and Caucasian refugees were placed by the Turkish Government. A digital copy of this map at a scale of 1:338000 was made in 1999 showing the same data. It details the origin of the population, differentiating between the native-born and immigrant Turkish populations. Although the expedition was terminated prematurely and therefore the map covered a smaller area than was intended, it is unique. The whereabouts of the second manuscript map and the rest of the material collected on the expedition is unknown.
\end{abstract}

Keywords: Lénard-expedition, Anatolia, ethnographic map, refugees

\section{Introduction}

In 1918 the Hungarian government decided to send a scientific expedition to Anatolia. The team was to be made up of experts and scientists, who were in active military service. They had scientific competencies to do the survey in areas of geology, technology, economy and ethnography. The results were to be the basis of the future trade relations between Hungary and Turkey. The expedition was mainly thanks to the work of Paul Teleki, who was the president of the Turán-society (Turáni Társaság) at the time. He chose the members who were to take part. Jenő Lénard was chosen to lead the expedition, but Teleki, who himself was a devoted scientist, wanted to make sure that as many scientific fields were represented as possible. The members were Dr. Gábor László, who was responsible of the geological survey, Rudolf Széchényi, who together with Lénárd were responsible for the economic survey, Emil Vidéky, who was responsible for the technical survey, and István Györffy who was responsible for the ethnographical survey. The expedition should have left in May 1918, but due to many organizational problems they only left in mid-September. The expedition, although it was cut short, explored an area of 12500 square kilometres. Two ethnographic maps at a scale of 1:200 000 were made of the area where many refugees from the Caucasus and the
Balkans were placed by the Turkish government. The map covers a smaller area than originally intended, it is still the only map known that map the ethnic composition of the area in such great detail at the . One copy of the map was brought back to Hungary by István Györffy. A copy of the map at a scale of 1:338 000 was made in 1999 with the same contents as the original.

\section{The Lénárd-expedition ${ }^{1}$}

The Lénárd-expedtition was the idea of geographer and cartographer Count Paul Teleki. No official record is kept of if Teleki would have liked to take part in the expedition, but it is well known that he did have other duties. Shortly after the expedition left Teleki started working on the geographical background for the peace talks ending the war, and made his famous ethnographic map of Hungary based on the density of the population. He later became prime minister of Hungary. All members of the expedition were picked by Teleki himself. The expedition was lead by Jenő Lénard (1878-1924), who himself served in the military. Jenő Lénárd born Eugen Isak Levy, was a German born philosopher and orientalist of Jewish decent, who after converting to the Lutheran

\footnotetext{
This chapter is based on the essays written by István Györffy. Spelling of place names is based on the way Györffy spelled them.
} 
faith in 1909 adopted the name Jenő Lénárd. He was a reserve captain in the Austro-Hungarian army. While the idea was to send people who members of the armed forces, it soon turned out, that the scientists, despite the fact that they were officially doing active military service, were not used to conditions that most military personnel was used to when performing wartime duties. This caused many problems during the first days of the expedition. The expedition left on 23 September 1918 from Haydarpaşa.

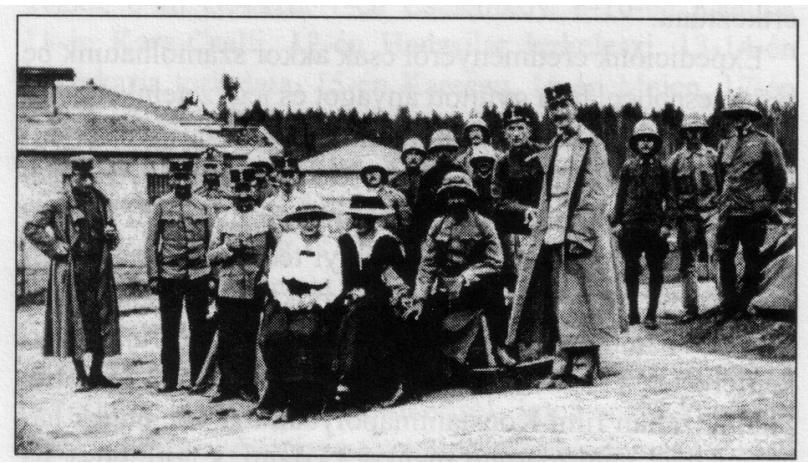

Figure 1. The members of the Lénárd-expedition before depature their departure (Picture taken by István Györffy)

The following route was taken ${ }^{2}$ (Györffy: 1921-1925) (The official names of the places that have been identified are written in brackets. The names are taken from the map. On the map the names were written using Hungarian phonetics):

- 21 September 1918: Hajdárpasa (Hya.darpaşa)

- 23 September 1918: Szuktari (Üsküdar/Scutari)

- 24-25 September 1918: Bulguri ${ }^{3}$ (Bulguru)

- 26 September 1918 Ömerlü (Ömerli)

- 27 September 1918: Hedzsizilü ${ }^{4}$

- 28 September-3 October: Sile (Şile)

- 4 October: Kurudzsuköj ${ }^{5}$

- 5 October Tekke (Tekeköy ${ }^{6}$ )

- 6 October: Gökszu (Göksu)

- 7 October: Cselebiköj (Çelebi ${ }^{7}$ )

2 Spelling of place names as they were recorded by István Györffy. Since it was not possible to identify all places, the same spelling is used in the whole text that Györffy used in his manuscripts. Where it was possible the official names are shown in brackets every time the name is used.

3 Probably a spelling mistake. In the subtitle of one of his pictures as well as on the map it is written Bulguru

4 Could not be identified

5 Could not be identified

6 Assumption based on the route

Assumption based on the route
- 8-10 October: Kandra (Kandra)

- 11 October: Kara-Csalli (Karaçali)

- 12 October: Hadzsilar Iszkeleszi ${ }^{8}$

-13-14 October: Szakaria (Sakarya) river mouth

- 15 October: Karaszu (Karasu)

- 16 October: Melen (Melen)

- 17 October: Akcse Sahir (Akçakoca/Akçaşehir)

- 18 October: Akkaja (Akkaya)

- 19 October: Alapli (Alaplı)

- 20 October: Csölmekcsiler ${ }^{9}$

- 21 October: Kurdlar ${ }^{10}$

- 22-27 October: Eregli (Ereğli/Erekli)

Already in Kandra the team heard news about the Bulgarian front collapsing, and on arriving in Elegri they saw that the Germans stationed there started packing up to leave. Captain Lénárd send a telegram to General Pomianovski, the commander of the common army in Constantinople ${ }^{11}$, asking him if they should continue with the journey under the current conditions. In a few day the reply came, that they should turn back. Vidéky and Széchényi boarded a ship to return, while the others decided to return over land. They took a different route on the return journey, making the expedition in effect longer than it would have been if they return on ship or on the same route they came. On 28 October the remaining team set off on the return journey. They took the following route (Györffy: 1921-1925):

- 28 October: Alapli (Alaplı)

- 29 October: Jenijer (Yeniyer)

- 30 October: Bekcsi ${ }^{12}$

- 31 October: Muhadzsirköj ${ }^{13}$

- 1 November: Hendek (Hendek)

- 2-3 November: Adabazár (Adapazarı/Adabazar)

- 4 November: Hadzsi Ibrahim Csiftligi ${ }^{14}$

- 5 November: Hereke (Hereke)

8 Could not be identified

9 Could not be identified

${ }^{10}$ Could not be identified

11 Officially known as Istanbul. Györffy used Konstantinápoly in his records. This is Hungarian for Constantinople

12 Could not be identified. Based on the route it could be a place near Düzce.

${ }^{13}$ Could not be identified. Based on the route it could be a place near Düzce.

${ }^{14}$ Could not be identified, but based on the route it is most probably Izmit 
- 6 November: Böjük-dere mountains ${ }^{15}$

- 7 November: Hajdárpasa (Haydarpaşa)

After returning to Haydarpasa some of the material that was collected was put in a place for safekeeping that they were intending to use after peace was made. Another part of the material they took with them. This eventually made it back to Hungary. On 1 December the team was taken to prisoner of war camps. Gábor László and Rudolf Széchényi were taken to Moda ${ }^{16}$, while Lénárd, Vidéky and Györffy were taken to Maltepe ${ }^{17}$. They boarded a ship for Trieste on 7 January 1919, and within 10 days arrived in Trieste, where they boarded a train headed to Hungary. They arrived back in Hungary on 21 January 1919.

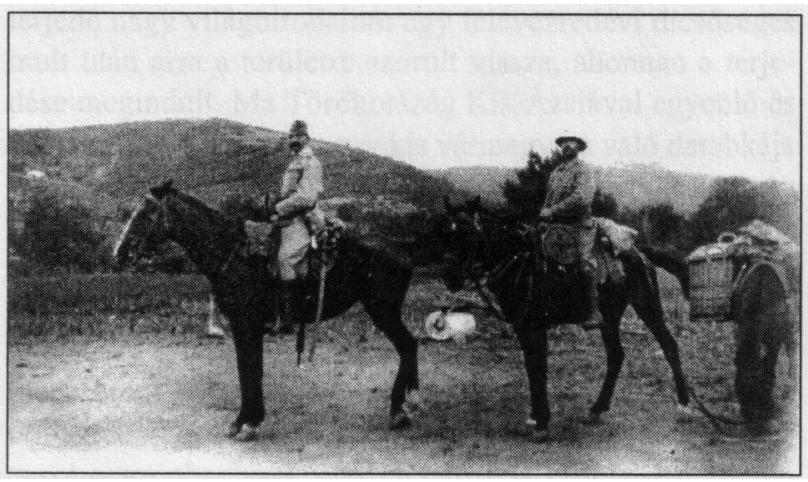

Figure 2. Jenő Lénárd on horseback during the expedition (Picture taken by István Györffy)

Towards the end of the expedition news of the Bolshevik revolution and the disillusion of Austria-Hungary began arriving to the team. The Austrian, Czech and Croat members of the team began a passive resistance, making their scientific work even harder. At the same time the leaders started loosing their hope in getting home. Following the arrival of the Entente forces on the shores of Anatolia, the Hungarian members of the team became prisoners of war. Most of the scientific material was placed in a safe place in Constantinople, while a small portion of it was smuggled back to Hungary. One copy of the ethnographic map made by István Györffy was placed in the safe holding, while the other was smuggled back to Hungary. Only a part of the films on which Györffy took photographs of the expedition were taken by the team to Hungary. Of the 650 pictures 150 remained in Istanbul. These were undeveloped, and Györffy wrote, that if these are not recovered very soon, their condition will deteriorate and they will be unrecoverable. Up until today no known records are available that anybody ever

\footnotetext{
${ }^{15}$ Could not be identified. Based on the route this refers to what is today known as Ballıkayalar National Park

16 Today a neighborhood in Istanbul

17 A district of Istanbul
}

recovered these, or that they were developed in order to preserve them. All written records and drawings also remained in Turkey. The map and these records, if found can probably be recovered today, while the photographs probably not, unless somebody developed the films. If the return journey from Ereğli to Haydarpaşa is taken into account the expedition lasted 50 days, and covered an area of 12500 square kilometres. Györffy focused his research on settlement geography ${ }^{18}$, so his drawings are probably show a lot of information regarding the settlements they passed. In his work prior to the expedition Györffy published maps of different settlements. During the Lénárd-expedition he made great effort to make records of the methods used in agriculture. According to Györffy the value of their results is increased by the fact that they were there in autumn, making it possible to observe things that cannot be observed in summer. Expeditions to Anatolia in general were conducted during summer time. The Lénárd expedition, if the delays would not have come about, would have also taken place in the summer months. This probably would have meant that the expedition would not have been cut short and the team could have returned to Hungary unhindered without having to leave anything behind, but the results they gathered in the autumn months would not have been gathered. At the same time the war caused a lot of hindrance for the ethnographic survey. Everybody who could be conscripted to the war effort was conscripted, so the men were missing from the villages. This also meant that it was not possible for them to visit village homes, since they could not enter home where the men were not present. In some cases they were not even allowed to camp in the villages, since there were no men in the entire village. No ornaments or objects of ethnographic significance were collected. In the first leg of the expedition the horses were overloaded, so it was not possible to carry them, while later the team saw no hope in being able to take these with them to Hungary. Györffy believes that collecting such items would have been a wonderful task during peace time, since all officials as well as the general public were happy to see them, and catered very well for them, when it turned out that they were Hungarians (Györffy: 1921-1925).

\footnotetext{
18 In Hungary urban geography does not only focus on urban areas, but also on rural settlements with a similar approach. The Hungarian term településföldrajz would be best translated as settlement geography, applying this approach not only to urban, but rural development.
} 


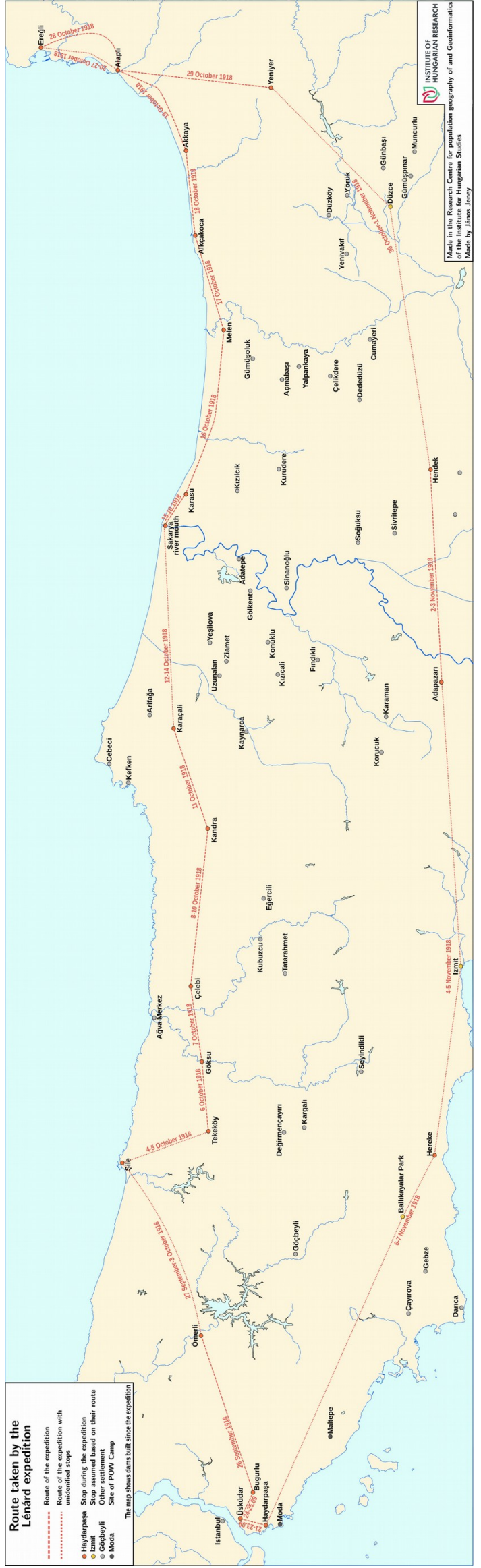

Figure 3. The route taken by the Lénárd-expedition (Map made by the author)

\section{The records of the Lénárd expedition by István Györffy}

István Györffy published essays between 1921 and 1929 about the Lénárd expedition. These were based on his records and memories of the expedition. In this chapter these writings are presented to show how he saw Turkey at the time. The purpose is not to give a full analysis for Turkey, but rather to present his works as well as the results of the expedition.

\subsection{István Györffy, the Hungarian ethnographer}

István Györffy (1884-1939) was a Hungarian ethnographer. He started his studies in Kolozsvár. He first studied theology, but later changed his courses to geography. Following this, in September of 1905 he moved to Budapest. He became an apprentice at the Ethnographic Museum in Budapest in 1906 with the help of the director Zsigmond Bátky. By virtue of the minister, he was also responsible for the Museum of the Eastern Trade Academy, which made it possible for him to take part on field trip to the Balkans and Turkey. His first observations of the Balkans was published in 1916. The most important result of this was the ethnographic map of Dobrudja, that was one of its kind, and never before or after this map was published was such a detailed ethnographic map published of Dobrudja. His ethnographic map of the Csangó ${ }^{19}$ areas in Moldavia became very well known and is studied up until today. Györffy, who spoke Turkish, joined the Lénárdexpedition in 1918 to do the ethnographic survey during the expedition (Klinghammer: 2015).

\subsection{Turkey through the eyes of the Hungarian ethnographer ${ }^{20}$}

According to Györffy no country has lost as much territory recently as Turkey ${ }^{21}$. The country that once spanned across three continents now occupies the same territory from where it once expanded. Today there area of Turkey is basically the area of Anatolia and a small area in Europe. Györffy adds that its capital Constantinople ${ }^{22}$ or in Turkish Istanbul ${ }^{23}$ is in most parts in Europe, but the area of Haydarpasa, which is part of

\footnotetext{
${ }_{19}$ Hungarians who live in Moldavia since before the First World War

20 These accounts are based on the writings of István Györffy, so they resemble what he observed in Turkey in 1918

21 Györffy published this statement on 1 January 1929

${ }^{22}$ Györffy in general refers to the city by this name, but he does make one note about the fact that in Turkish it is called Istanbul. This is probably due to the fact that this is how it was known in most of Europe at the time.
} 
the city, is in Anatolia. He states, that although Turkey, similarly to Hungary lost a large portion of its territory, it is today still a large country ${ }^{24}$. He explains that Turkey is surrounded by seas from three sides, and most of it is mountainous. Towards the east in the Caucasus most tribes living there are Turkish tribes or at least follow the Islamic faith, who live under Soviet rule ${ }^{25}$. The other neighbour as written by Györffy is Persia, which in the border region is inhabited by Turks. Its neighbours towards the southeast are Mesopotamia and Syria. These areas according to Györffy were taken away Britain and France from Turkey. He gives a very good description of Turkey. Some comparisons are made to Hungary. One of these interesting comparisons is that he states that Turkey does not have a lot of forests, and cannot supply enough wood for its own needs. He states that they are even worse off in this regard than Hungary. While Turkey hardly has wood, Györffy observes that the main building material used for their houses is wood, and the main energy source for heating and cooking is charcoal. He also states that the land is mostly used for grazing, and that most of the rural population grows livestock. The soil is fertile, and could be used for agriculture, but since the roads are bad, and the products cannot be sold, they only produce enough for their own needs, leaving the rest of the land to be grazing grounds. They do not harvest hay, since the livestock can graze from beginning of March until Christmas. In the winter even the horses are fed straw. He observed that in Turkey just about everybody rides a horse. They even encountered beggars who were riding a donkey. He also observed that in Turkey there are still a number of people who live a nomadic life, herd their livestock and live in tents.

${ }^{23}$ At the time of the expedition this was the capital city of Turkey. Although his writings were first published in 1929, they are based on sources gathered during the expedition, so have to be read in that context.

${ }^{24}$ An attempt was made to cede large territories from Turkey in the Treaty of Sèvres. This was prevented by the Turkish War of Independence. Many compare the Treaty of Sèvres to that of the Treaty of Trianon, since the former would have caused a similar magnitude of territorial losses for Turkey as the latter caused for Hungary.

25 According to the original text he wrote "for now". This gives the impression, that Györffy regarded this situation to be temporary. Today it is known that these areas were part if the Soviet Union for 71 years following the expedition.

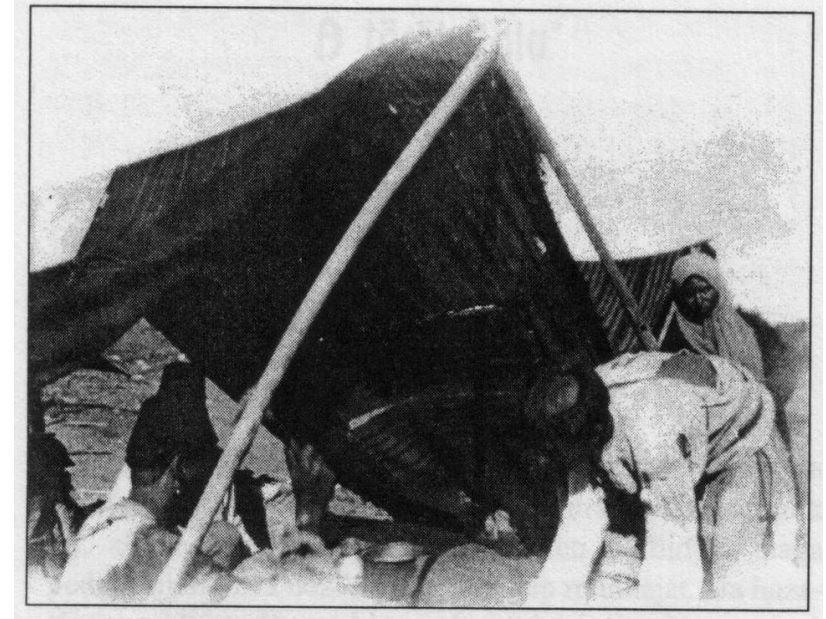

Figure 4. Yörük living in tents (Picture taken by István Györffy) He also observed, that while the cities were large and densely populated, the villages were small with a maximum of 30 houses. The villages are very close to each other, about 2-3 km apart. Some Turkish villagers move in Spring to the mountains and then move back in autumn. They take their livestock with them. These villages are uninhabited during the summer months, until their inhabitants, return for winter. These people are different to the nomadic people he observed, since they do not live in tents, but rather have a house in the summer village in the mountains and another in the winter village. This means that either the summer or the winter village will be uninhabited at a given time.

Their houses have two stories. On the lower level they have the stables, while on the upper level they have their living area. The house has at least two rooms, one for the husband, the other for the wife. Many in Hungary believe that the wives are locked in their room, and party there all day. In realty, states Györffy, it is very rare for anybody to have two or more wives, and the women have to work really hard to survive. He also observes that the rural women do not cover their faces. The women cook, milk the cows, do the washing sew cloths and bring up the children. The men work with the livestock during grazing times or work in some sort of handcraft or woodwork (Györffy: 1929a).

\subsection{The Turkish village}

Györffy has the impression that the Hungarians imagine the Turks as people who use Christian slaves to work their land and lives in luxury. He immediately states that it could be possible that 2-300 years ago somebody could have met such people from Turkey, but today (that is in 1918) no such people can be found in Turkey. All their treasures were taken by other great powers and today the 
Turks have been deprived of all they had ${ }^{26}$. According to Györffy, many who write about Turkey describe the situation in Constantinople ${ }^{27}$. This would be, according to him, the same as if those writing about Hungary would only describe Budapest and state that the whole country lives like those in the capital. He attempted to describe the villages in the way he saw it in Anatolia. It must be noted, that the expedition did not explore the whole of Anatolia, rather only a small portion of the northwestern part. As he saw it, the Turkish peasant has not changed its way of life for centuries. Its way of life has not developed the way it has in many other parts of the world. The Turkish peasant produces everything that is needed to cater for his and his families own needs, but not more. Györffy found the rural population to be very honest and hospitable. About three days after they left the capital, the roads as one knew them at the time in Europe disappeared. If somebody would have wanted to set out to Anatolia with a horse drawn carriage they would not get very far. Not only do Turks travel excursively on horseback, they also prefer to move their goods on horseback, since the carriages would not get very far. A very little portion of the goods is moved using oxwagons, but even these are loaded only to the extent that would be drawn by some of the weaker horses in Hungary. As stated earlier most villages are made up of about 30 houses, but some only have 8-10. While some villages are only inhabited in summer or in winter, others are not inhabited at all. About 8-10 villages build a church $^{28}$, some administration buildings, shops and a market around it.

\footnotetext{
${ }^{26}$ This expedition was at the end of the First World War. Turkey was on the side which lost the war.

27 The name was used in Europe at the time for Istanbul, and Györffy repeatedly used this name. He only mentioned the name Istanbul one in his writings.

28 This is the exact word Györffy used. It is unclear if he really meant a church or a mosque.
}

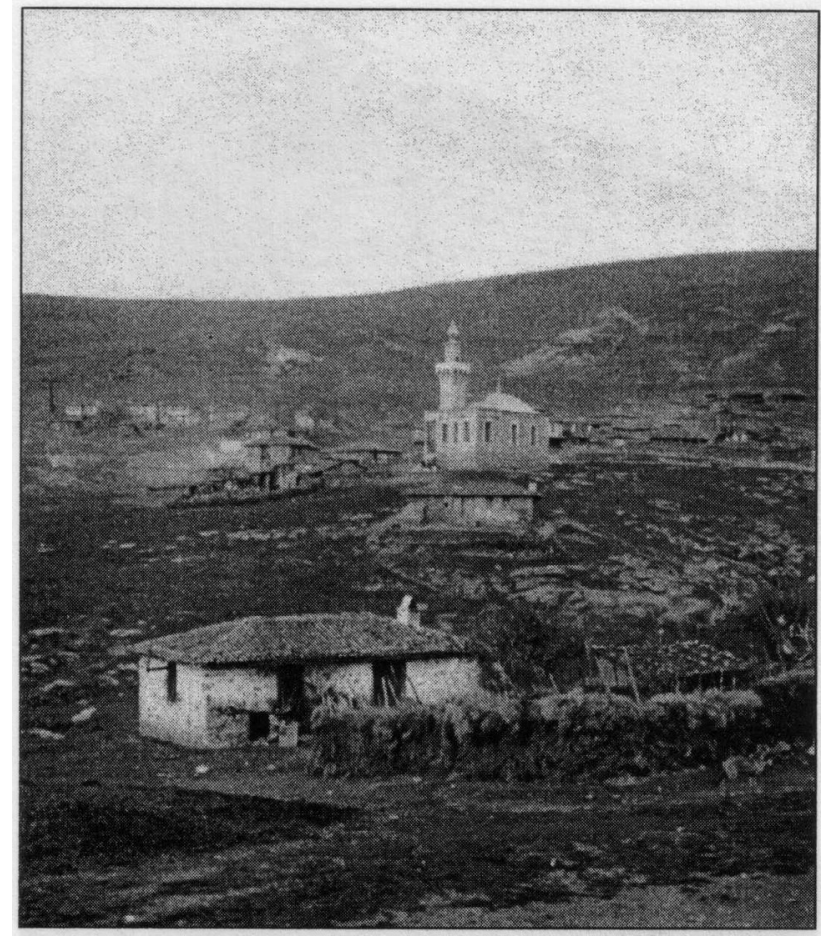

Figure 5. A Turkish village (Picture taken by István Györffy)

These are only visited during times of worship, shopping and in cases when some official issue has to be dealt with. In villages the houses are very close to each other and the properties have no fences. The agricultural work is carried out on the outskirts of the village. While many might think at first look that the houses are in a bad state, they are very comfortable from the inside. Many are not painted on the outside, but extreme care is taken on how everything is kept in order inside the house. As observed in the previous chapter, the houses have two stories, and the staircase leads from the stable up to the living area, where the man and the woman has their own room. They also have a kitchen and a storeroom. Györffy believes, that about one in a hundred Turks have two wives, and about one in a thousand have three wives. As he sees it, it is much harder to get married than in Hungary. The Turks have to basically buy their wives from the girl's parents. The cost of a girls is a few cattle and some goods that are not easy to get hold of. No woman, regardless of if they a married or not cover their face in their own village. Some cover it up to their nose when visiting another village, but even this is becoming very rare.

The inside of the houses is very clean. Everybody takes their shoes off when entering the house. One cannot find any chairs in the house, everybody sits on the floor, which is extremely clean. The table is round and is about $15 \mathrm{~cm}$ high. They don't keep the table permanently in the room. It is brought in when they want to eat with all the cutlery and food on the table. When they are done eating the table is removed from the room. The wardrobe is built 
into the wall. They have no beds in Turkish villages, they sleep on the floor.

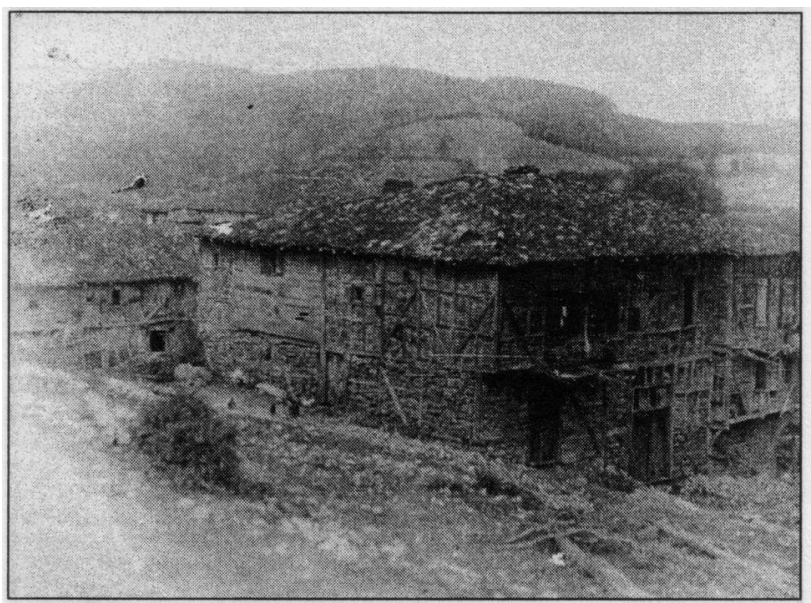

Figure 6. Rural Turkish house made of wood (Picture taken by István Györffy)

Györffy found that the Turkish peasant likes to be outdoors or in the stable with his livestock while the women work all day. Györffy observed, that unlike in Hungary, in Turkey the men give out the orders to the women and the women do the work. He believes this is due to the fact, that since the men had to pay for their wives, they expect to get the money they spent on them back. The women cook, do the washing and the sewing, raise the children, work the garden and if needed do the harvest. The men mostly work with the livestock. Györffy observed that the Turkish men enjoyed working with livestock. They do however do the work that their wives cannot do.

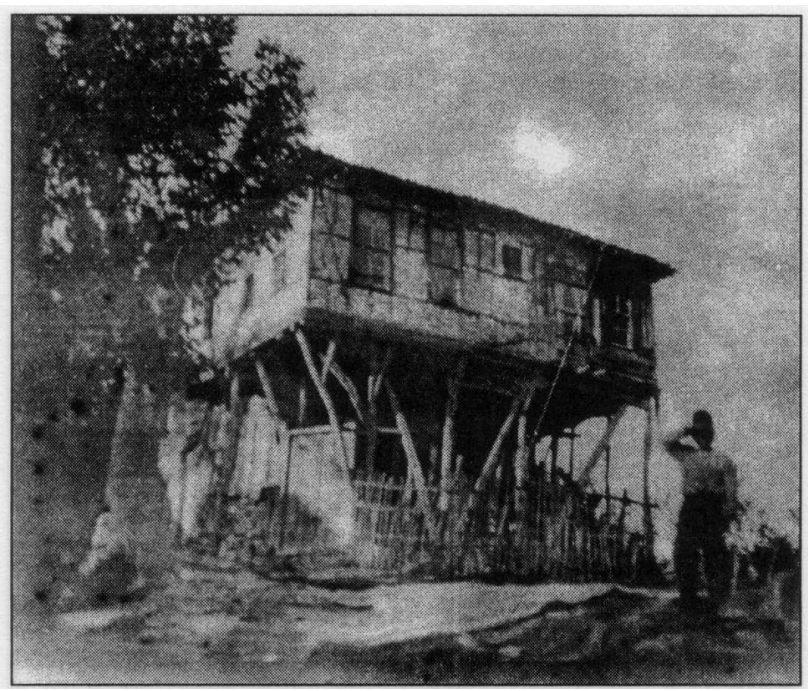

Figure 7. A house in Ereğli made of wood (Picture taken by István Györffy)

In the countryside there is a shortage of water. Most areas are bare, and if forests do start growing the trees are very short. Diffing wells is not possible, and the springs are often far from the villages. These are appreciated by the locals, and they often build buildings over them, and the water is lead in pipes over great distances. It only rains in the winter time. Partly due to the water shortage, the land does not bring many crops, but as stated earlier, he emphasis, that the land is not farmed efficiently.

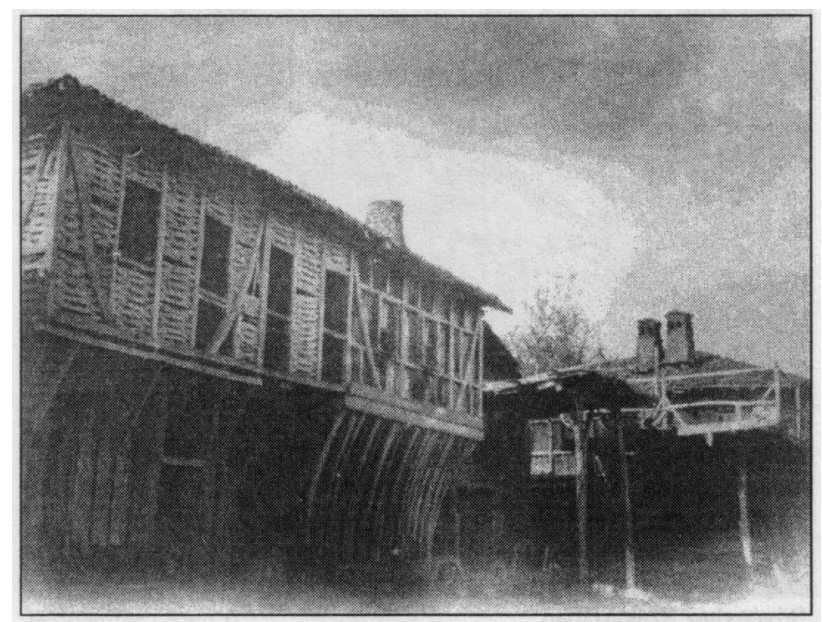

Figure 8. Wooden house in Şile (Picture taken by István Györffy)

He observes, that if they do find a tree they tend to cut it down. However olive trees, fig trees and grapes grow very nicely on the land. On the shores of the Black Sea there are forests with chestnut trees. The chestnuts do not end up on the market. The locals collect enough for their own needs, the rest falls down and is left under the trees. These are eaten by the boars. Boars are not hunted in Turkey, since the locals do not eat their meat, since they believe that it is not clean. There is an overpopulation of these animals, and these do cause a lot of damage in the few crops that are grown. At night one can hear these as well as the jackals making a noise (Györffy: 1921).

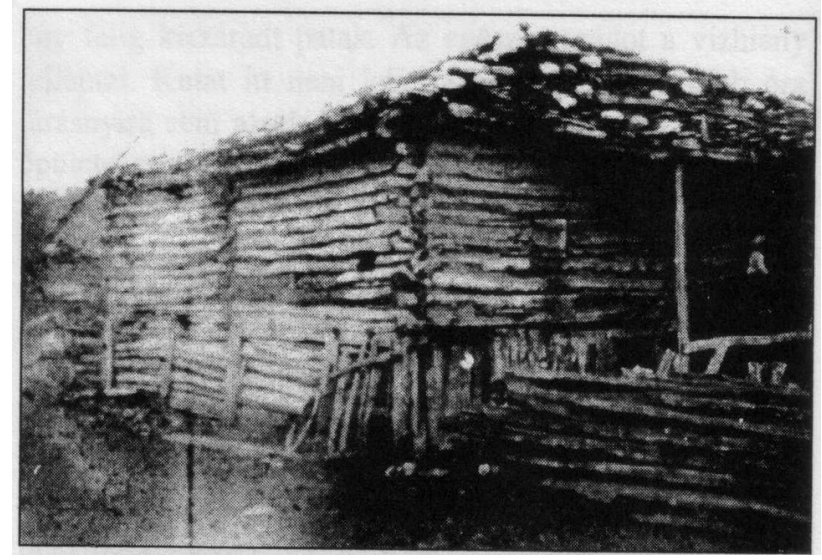

Figure 9. Greek house in Urumbar (Picture taken by István Györffy) 


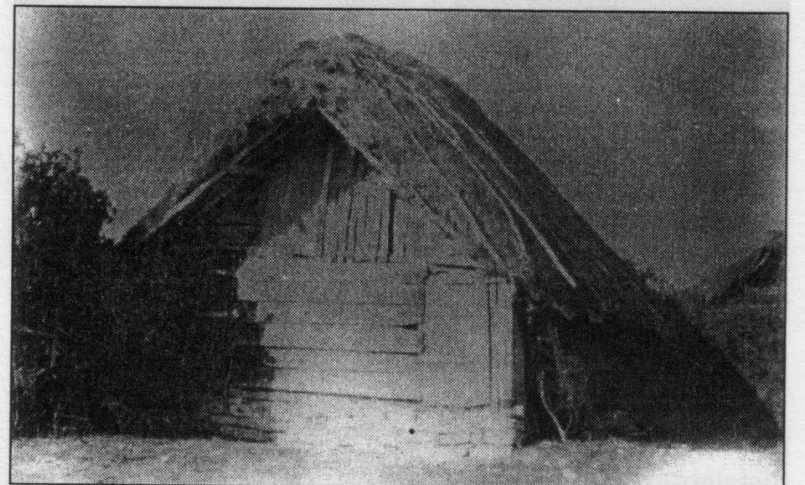

Figure 10. Turkish hut (Picture taken by István Györffy)

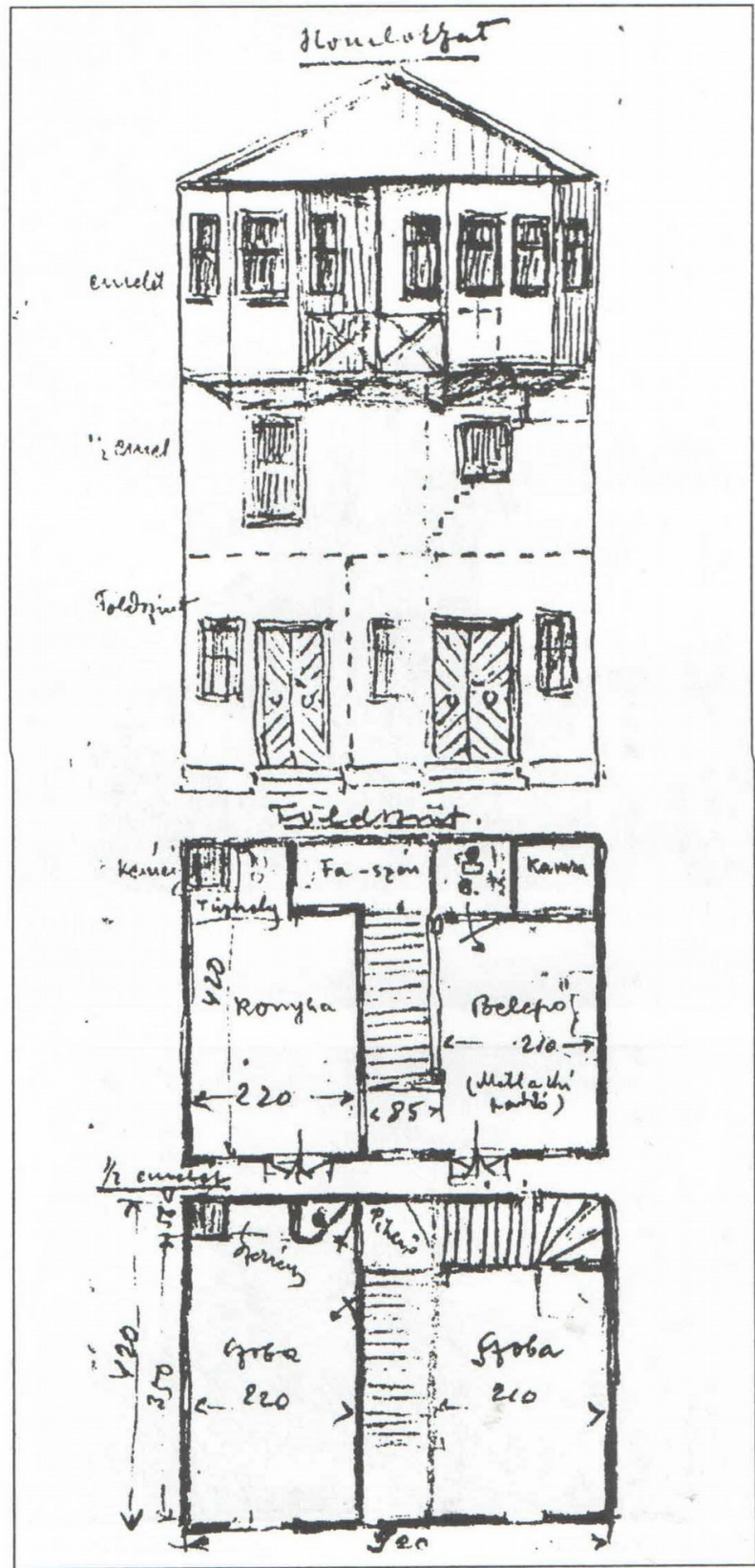

Figure 11. Survey of a Turkish village house drawn by István Györffy

\subsection{The Turkish Folk Art Through the Eyes of István Györffy ${ }^{29}$}

Györffy observed that Turkey at the time was not a very industrialized country, while handicrafts are very common. He believes that the industrialization of a country effects handicraft in a negative way, so the less industrialized a country is, the more handicraft can be found in the country. In Turkey exactly this could be seen: while there were very few factories nearly every village had somebody who was making some sort of small industrial item or some hand made ornament. Since a lot of people did handicraft in the villages, a lot of folk art was available. Györffy observed that the availability of folk art in Turkey was infinite. The folklore clothing of the Turks is very decorative. He believed that many elements in the Hungarian folk dresses originate from Turkey. At the same time, he also observed that the women in Turkey did not dress in such decorative dresses in public as the European women do. They did however spend a lot of time at home doing art, so the dresses they wore at home are much more decorative than what they wore in public. Turkish women, as he saw it, were very good at weaving carpets. Every region had its own unique pattern in that the carpets are woven. These were already then known worldwide. The most decorative carpets, with the most attractive colours are the knotted carpets. These are often called Persian carpets in Europe, but in reality there are made not only in Persia, but also in Turkey.

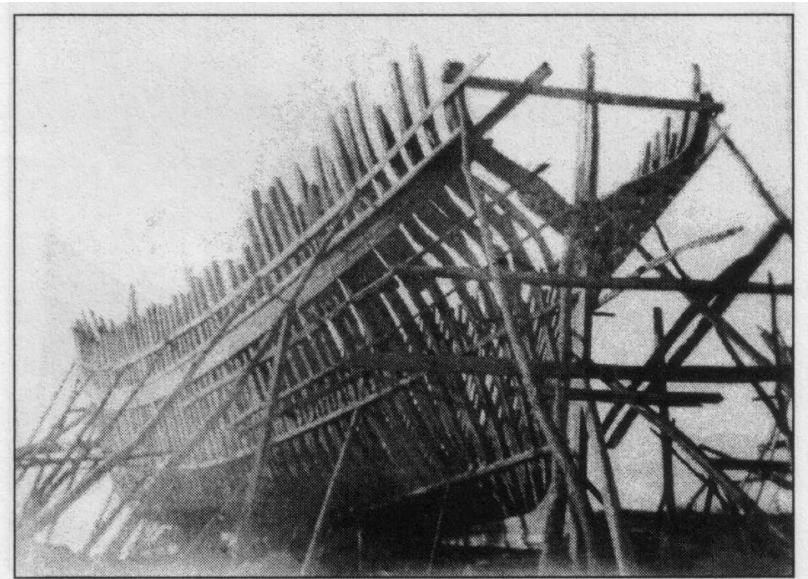

Figure 12. Shipbuilding in Turkey (Picture taken by István Györffy) He observed that Turkish women are very talented at making embroidery. These are usually made using threads made of silk, gold or silver.

29 This chapter is based on the publications of István Györffy from 1929. It is important to note, that while he wrote about this in 1929, his observations were done in 1918. Although he dies mention Turkey, it has be taken into consideration that his observations were done exclusively in the area that they covered during the expedition. 


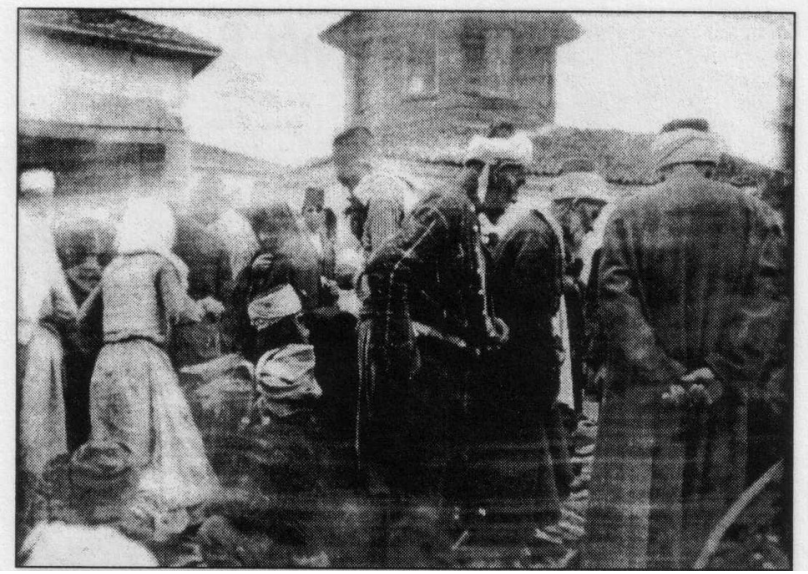

Figure 13. Market in Düzce (Picture taken by István Györffy)

Decorating embroidery with motives showing flowers is very popular. Most flowers are depicted in a bouquet. The geometric shapes found on European embroidery are very rare in Turkey, but embroidering Turkish writing is very common ${ }^{30}$. Often the customers got a very nice letter written on a decorative piece of embroidery that they ordered from the folk artist. Many of these patterns are well known throughout Europe, since a lot of Turkish embroidery and carpets end up on the European market.

The Turks are not very good at carving wood, since the country has very little of it. The wood that is available is used to build their very good quality two story houses. The Turkish shipbuilders, who are world famous, also build their ships of wood. While they do not carve wood, they do carve stone. The gravestones in the Turkish cemeteries are real relics, with even the writing carved in them in the most beautiful script. Every small village has at least two or three of these carved gravestones. The Turkish are very good at making ornaments out of iron, although their most beautiful metal ornaments are made of copper and silver. Pottery is also very popular in Turkey. All cities from the smallest towns to the capital city have markets that are exhibitions of these ornaments (Györffy: 1929b).

\footnotetext{
30 Györffy himself notes in his writing published in 1929 that until recently the Turkish language was written using Arabic-Persian script. The embroidery he saw while in Turkey were written using Arabic-Persian and not Latin script.
}

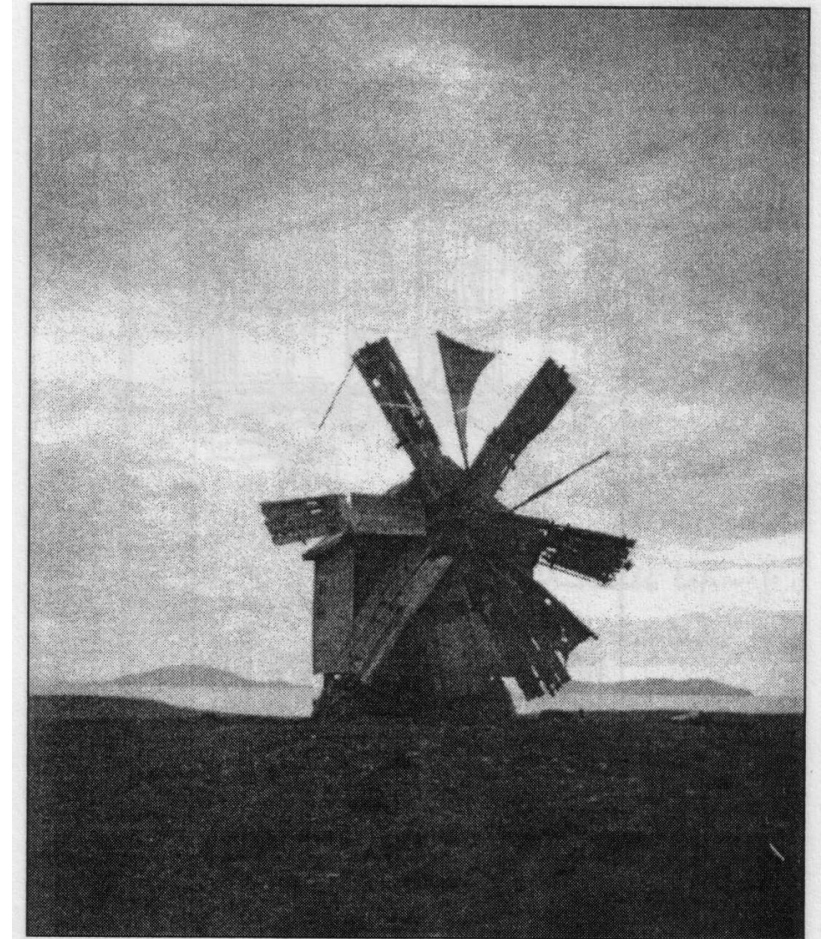

Figure 14. Windmill in Maltepe (Picture taken by István Györffy)

\subsection{The Future of the Turks though the eyes of István Györffy $^{31}$}

Turkey was regarded as a "sick man" until the beginning of the First World War. According to Györffy, this was greatly due to the intervention of the Western Powers. He believed that Turkey was not independent until Mustafa Kemal Atatürk did not end the interference by Western powers in Turkey, while at the same time creating a modern state. The women were banned from covering their faces and girls had to attend school. The Turkish alphabet was changed from the Arabic script to Latin script. Györffy believed, that although these reforms were not supported by any of the countries neighbours, Atatürk realized that he could not gain any support from these countries, which were ruled by one of the Western powers. Atatürk decided to turn Turkey into a nation state that would primarily depend on its own resources.

Györffy believed that Turkey would accept any help that is to its advantage, but having learned from the past they will only accept help from nations who do not pose a threat to the future of the country. According to Györffy, traditionally Turkey has a very warm and friendly relationship with Hungary ${ }^{32}$, and so accepted help from

31 This chapter shows how István Györffy saw the situation in Turkey at the time.

32 The original mission of the Lénárd-expedition was to create the basis of the future of the economic relations between Hungary and Turkey. 
Hungary with great gratitude. The Hungarians were doing very well in Turkey, where they were seen as the brothers with swords ${ }^{33}$.

Györffy believed in 1929 that the economy of Turkey was going to start booming very $\operatorname{soon}^{34}$ to come. The country is rich in minerals and raw materials. Some of these are just lying around on the ground, and up until then nobody bothered to do anything with them. Only seven percent of the land was cultivated at the time of the Lénárd-expedition. This was mainly due to the fact that Turkey lacked a public road system and a rail network. The Turkish roads, as Györffy experienced it during the expedition were unfit for use by vehicles such as those that were used in Europe, making it difficult to get to the lands or to move harvested crops from the land. The Turkish carriages, that were mostly ox drawn carriages could only move small quantities of goods. The situation was further worsened that Turkey lack bridges, so many routes were cut off. One of the first things that Kemal Atatürk did was to build roads and railroads, making it possible to cultivate much of the land that was not utilized up until then. Many great swamps in the country were drained and became fertile cultivated land. These swamps used to spread malaria making the ill and unable to work. A lot of machinery need for these projects was provided by factories in Hungary. The old inefficient tools fell out of use. When Turkey started to renew its livestock, a lot of livestock was shipped from Hungary to Turkey. If Turkey continues on the same economic path it will become an economic superpower and instead of being the sick man of Europe it will be one of the important nations again (Györffy: 1929c).

\subsection{The Ethnographic Map of Anatolia}

On their journey the István Györffy, being an ethnographer who was also an expert at making ethnographic maps, made two maps at a scale of 1:200 000 showing the origin of the population on the territory covered by the expedition. Although he left many of his records in Turkey, he did bring back one of the two maps he made. The other was left for safekeeping in Istanbul, from where it has not been recovered up until today. The reprint made in 1999 at a scale of 1:338000 was made based on the map that Györffy managed to bring back with him to Hungary. The area they covered is an area where the Turkish government settled the refugees from the Balkan wars, so large immigrant populations lived there at the time. Györffy defined four categories of

\footnotetext{
33 This was regarded by Györffy as a very friendly gesture from Turkey

34 The essay was published in February of 1929, and hence before the great depression
}

Turks: Turks who are native to Anatolia, the Yörüks ${ }^{35}$, immigrants from Rumelia ${ }^{36}$ or the Transcaucasus ${ }^{37}$ and the Kizilbash ${ }^{38}$. He also has a separate category for the Tatars. The peoples of Turk origin are depicted in different shades and patterns of red and orange in the reprint. The peoples with origins in the Caucasus are depicted in light blue and light green. The Cherkess are spit into two categories: ones from Adygea and ones from Abkhazia. Other peoples from the Caucasus are the Laz (Lazi) and Georgians. He also made further categories for the Kurds, Armenians, Persians, Poles, Greeks, Gypsies ${ }^{39}$, and Jews. On the 1999 reprint very similar colours are used for the Jews and the Turks native to Anatolia, so these categories are very hard to distinguish. It is not known if this was the case on the original map, as neither of the twos maps was seen by the author. While it is documented that the data is based on the original map made by István Györffy, no reference is made to the fact if the legend was changed on the map. Since this is a digital remastering of the original map it is possible that the colours in the legend were changed. The map has white areas with no data available. This is due to the fact that the expedition was cut shot, so these areas could not be surveyed. The map uses coloured surfaces and does not take into account the density of the population, thus only showing the dominant population in a particular area. It has to be noted that that Györffy did write in his essays about the excursion that they were in a hurry, so mapping also had to be done quickly. Besides mapping, he also had other duties to attend to, like taking photographs, many of which are taken from horseback, since there was no time to get off and look around. It is interesting that the data about different nationalities shown on the map is not detailed in his essays. He did however take pictures of Greek houses. These are not described at all, while Turkish houses are described in great detail. Ethnographic description of the other nationalities is not touched at all, he merely writes about the fact that they live in the area. Nationalities are only shown in Anatolia, despite the fact that a very small portion of the European area of Turkey is also shown. The areas of Istanbul that are in Anatolia do not show

\footnotetext{
35 These people of Turkish origin are native to Southern Anatolia. The map only depicts Northern Anatolia

36 The Balkans under the Ottoman rule

37 An area in the Southern Caucausus

38 Györffy used the term kizilbas known in English as Kizilbash, or as they are more commonly known Qizilbash

39 This term was commonly used at the time for the people of Roma origin. Györffy used the Hungarian word cigány on his map, which is the Hungarian word for Gypsy
} 
population data either. The only railway on the map runs form Istanbul to Adabazar (Adapazarı) over Izmid (Izmit). The harbours are also shown, as are the roads and the larger settlements. The place names use in some cases use same spelling that was used by Györffy, while others use the current official Turkish spelling. Istanbul is written Konstantinápoly which is Hungarian for Constantinople. Not all places noted by Györffy as stations of the expedition are on the map. The names used by Györffy are how he transcribed the Turkish names written using Persian-Arabic script into Hungarian (which uses a variation of the Latin alphabet). Turkey only adopted the Latin script in 1923, so when Györffy was in the country the official language was written using Persian-Arabic script. Some names have also changed since then, furthermore some names used in Hungary as well as in most Western countries were often not the Turkish names. The most notable example, which is often used in his writing as well as on the map is Constantinople. This city, which was the capital of Turkey at the time, was known in Europe as Constantinople, while already then it was called Istanbul in Turkish. Györffy only mentions the Turkish name once.

The northern part of the map is the Black Sea coast, the Southern part is the gulf of Izmid (Izmit) (and further east along the same latitude), in the western end of the map is Istanbul (they left from Haydarpasa, which is a part of the city in Anatolia) and in the East is Eleğri, which is the point where they turned back. From the map it can be clearly seen that areas in the western part of the mapped territory have minorities from Europe and the Caucasus (Poles, Jews, Greeks, Cherkess, Laz, Georgians and Armenians and Turks from the Trancaucasus and Rumelia ${ }^{40}$ ). In the very western part of the territory, most peoples from the Caucasus are in one area, with only some of the Laz scattered in area with Turkish majority. The Greeks are scattered in the coastal areas, while some poles are scattered just east of Istanbul. Although some immigrant Turks from Rumelia and Transcaucasus do live in the western part of the mapped territory, their numbers increase as one heads east, where one also finds the Yörüks and the Kizilbash. Some Armenians live in the western part, but their numbers also increase as one heads east. In the south, the areas east of Izmid are very diverse. The north is less diverse although there are some minorities around Kandra. East of Incili the north also becomes somewhat diverse, although to the east of the Akçe Şehr - Üsküb line the majority of the population is

40 The Turks from the Transcaucasus and Rumelia are depicted in one category, so it is not possible to determine which of the two groups lives in which area.
Tukrish, and only a few areas have Greek and Georgian population, although there are a very small number of Kizibash, Laz and Geogians as well. The Cherkess from Abkhazia are almost exclusively in the south-eastern areas. Their numbers increase as one heads east in the diverse area.

In the eastern part of this area they inhabit large areas, making the area somewhat less diverse, although they do still mixes with other groups. The ones from Adygea are also mostly in the south-eastern parts, but a few can be found around Incili in the north as well as some in the western parts southwest of Sile (Şile). They too inhabit larger areas as one heads east. The areas where this group inhabits larger areas are to the east of the areas inhabited by Cherkess from Abkhazia. The two Cherkess groups are the largest minorities on the map. In fact the two combined make up most of the eastern part of the southeastern diverse area. Most of the Laz are scattered in the Southeast, but smaller numbers can be found all over the map, especially in the most western parts. The Yörük are one of the smallest groups on the mapped territory. They can only be found in small numbers in the diverse area in the southeast and another area in the northern part, north of the Göl köprü gölü. Poles and Jews are not seen in the eastern areas. The Gypsies (Roma) are scattered in the entire eastern part of the territory not only the very diverse southern parts. Another very small group are the Tatars, who are also only present in very small numbers in the diverse southeastern areas. The Kurds, who are present in small numbers in the eastern and southern part of this diverse area, are scattered throughout this part of the territory, but are not found in any other parts on the map. Although most Greeks live outside the diverse area, a small number of them live in this area. The only groups that cannot be found in this area are the Poles and the Jews, while the Tatars and Kurds, while the Kizilbash are only found in very small numbers in this area and who are also present in small numbers in the area on the eastern edge of the map. Of the Yörüks and the Cherkess from Abkhazia only a very small portion of their population in Northwestern Anatolia lives outside this diverse area. The Laz, Georgians, Cherkess from Adygea, the Armenians and the Turkish immigrants from Rumelia and Transcaucasus are scattered all over the map, although the largest area with Turkish immigrants is in the Western part of this diverse area. Most areas inhabited by Greeks in this diverse territory are very small, with only one large predominately Greek area in the north. Most Greeks live outside this area in the coastal regions, both in the southern and northern part of the mapped territory. 


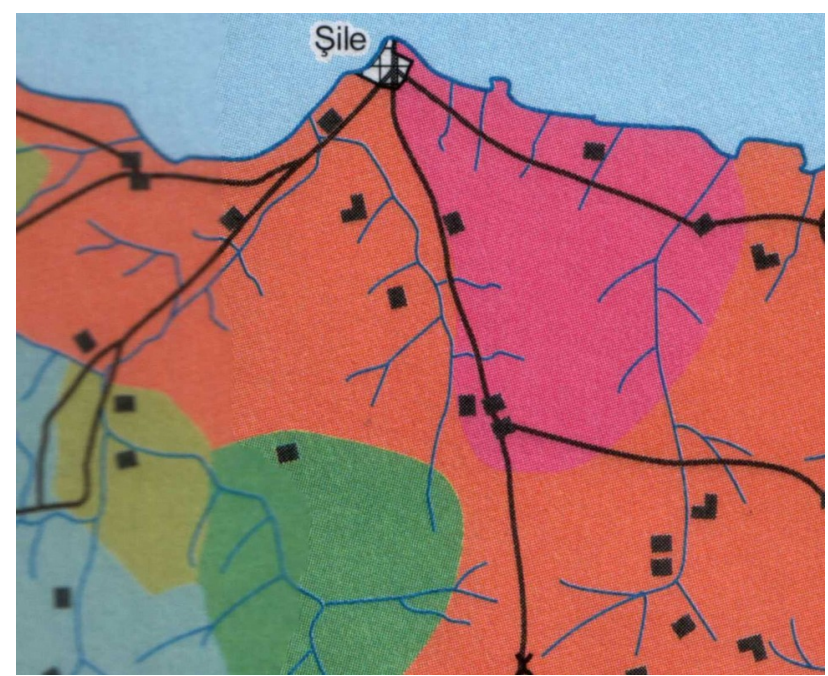

Figure 15. Area around Şile. Orange depicts Turks native to Anatolia, pink Greeks, dark green Georgians and light green Laz. (Map based on the map by István Györffy, made by Márta Satek and János Györffy)

One unique feature of this diverse area is, that is is the only large area on the map where the Turks native to Anatolia are a minority. In fact in the eastern and northeastern part, the Turks, both native and immigrant, are a minority, while in the western part, when one adds the areas with native and immigrant Turkish population they do make up the majority. The Greeks and the Laz, although in numbers make up a large minority on the whole map, there are no large contiguous areas that are inhabited by them. The Armenians, who are also scattered all over the mapped territory, altogether inhabit much a smaller area than the Laz and the Greeks. All areas outside the diverse area are inhabited primarily by native Turks from Anatolia. Some parts of the diverse area have no data, as is also the case for some parts of the eastern areas on the map. This is due to the fact that the team had no time to gather this data since the expedition had to be cut short. Originally a much larger area would have been mapped if the expedition would have been carried out in full.

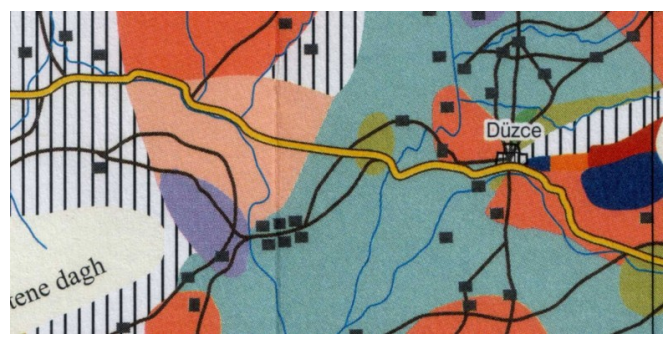

Figure 16. Area around Düzce. Orange depicts Turks native to Anatolia, pale pink Turkish immigrants from Transcaucasus and Rumelia, light blue Cherkess from Adygea, striped area Cherkess from Abkhazia, light green Laz, purple Kurds, bright orange Jews, red Tatars and dark blue Armenians (Map based on the map by István Györffy, made by Márta Satek and János Györffy)

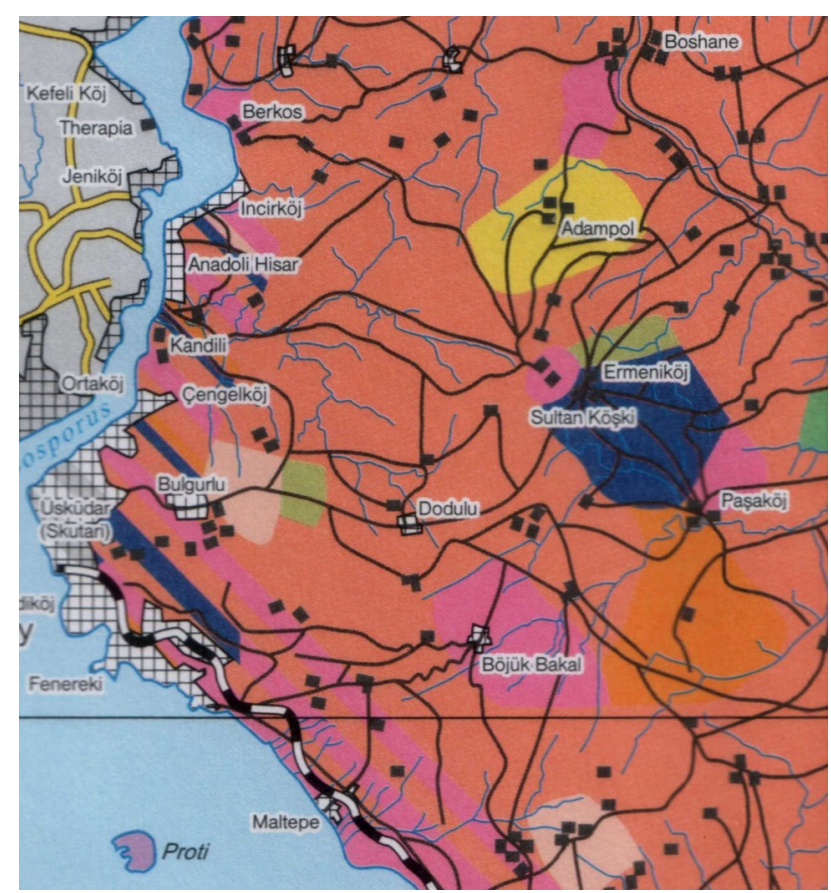

Figure 17. Western part of the map with Haydarpaşa in the west. Orange depicts Turks native top Anatolia, bright orange Jews, yellow Poles, dark blue Armenians, pink Greeks, pale pink Turkish immigrants from Transcaucasus and Rumelia, light green Laz and dark green Georgians. (Map based on the map by István Györffy, made by Márta Satek and János Györffy)

Although the fact that the expedition was done in autumn had a lot of benefits as far as the ethnographical survey is concerned, they probably would have mapped a much larger area if they would have left earlier, since the reason for cutting the expedition short was the fact the central powers lost the war, of which both Hungary and Turkey were part of. Being men who were in active military service for the central powers, their free movement was undesired by the allies after Turkey surrendered, so the team was split and interred in prisoner of war camps.

Györffy made no reference to the fact in his essays if the two maps he made are identical or not, so it is not known if the map that was left in Istanbul is any different to the one that he took back with him to Hungary, but it is very fortunate that this map was taken to Hungary, as it was available for the cartographers who made the 1999 publication. This is the only map known today that shows the refugees from the Balkan wars of 1912 and 1913 in Northwestern Anatolia. It is the most detailed map showing the origins of the population in the area, and is the only map made of any area of Turkey that shows this in such great detail.

Despite the fact that the team had to hurry, the expedition was cut short, and towards the end they were demoralized, first by the news they were getting from the 
lost battles of their side and later by the war being lost by their side the map is a unique masterpiece, since no map has been made like it ever before or ever since.

Györffy managed to hide this map, as well as many photographs and other data after returning to Istanbul. Györffy was a prisoner of war with half of the team in Maltepe, while the other half was kept in Moda, until they boarded a ship to Trieste on 7 January 1919, from where they traveled by train to Hungary. The journey to Trieste lasted ten days, and they returned to Hungary on 21 Januar 1919. István Györffy published many publications about the excursion between 1921 and 1929 after his return from Turkey. His map was just about forgotten after the second world war, and only in 1999 was it digitally remastered and published. This was the first and only time it was published in mass print.

\section{Conclusion}

It is clear that István Györffy respected and admired the Turkish people. He firmly believed in friendship between Hungary and Turkey, and saw a very bright future for Turkey. As a Hungarian he always compared this findings in Turkey to the situation in Hungary, since most of his ethnographic surveys were done in Hungary, although he also had substantial experience from the Balkans and Moldova. His work helped greatly in improving the general image of Turkey in Hungary, which helped evolve the friendship between the two nations, which was one of the goals he openly declared.

His map is very unique. Making this map was not a primary goal of the expedition, but it can be considered one of the very important results, although many of the results, including the second, are still missing as they have never been recovered from the place where it was left for safekeeping. The map is very detailed and the only one of its kind. One can say it recorded the state that has not been recorded by any other cartographer. Today the demographics have changed in the area so reconstructing this without his map would be very difficult. Probably the most important information recorded by the map is the where all the refugees were place. The map definitely shows a much more diverse picture of the area in 1918 than what was widely known. It is however unknown if the area to the east of the mapped area would also have been so diverse. The party did intend to cover it, but the expedition was cut short. Despite this, the map is the most detailed cartographic document showing the peoples of Northwestern Anatolia during the First World War.

\section{References}

Györffy, I. (1921). A török falu (The Turkish village). A falu, 15 November 1921

Györffy, I. (1929). Törökországról (About Turkey). Levente, 1 January 1929

Györffy, I (1929). A török nép és életmódja (The Turks way of life). Levente, 15 January 1929

Györffy, I. (1929). A török népmúvészet (Turkish folkart). Levente, 1 February 1929

Györffy, I. (1929). A török nép jövője (The future of the Turks). Levente, 15 February 1929

Klinghammer I. (2015) Tudomány - politika - térkép. Györffy István balkáni és törökországi néprajzi térképezése. Külügyi szemle 2015/4. p. 141.

Németh, Gy. (1921-1925). A Lénárd-féle kis-ásiai expedíció . Körösi-Archívum no. 1

Bartha, J (2001). Györffy István írásai a Balkánról és Törökországról (István Györffy’s papers about the Balkans and Turkey). Terebes Kiadó, Budapest

\section{Origin of the images}

The photographs and extracts of the ethnographic map originate from the book Györffy István írásai a Balkánról és Törökországról (István Györffy’s papers about the Balkans and Turkey) edited by Júlia Bartha, published by Terebes Kiadó in Budapest in 2001. 